\title{
Repositioning Ourselves: acknowledging contradiction
}

\author{
Um reposicionamento: reconhecendo nossas contradições
}

\author{
Dana Cox ${ }^{*}$ \\ Beatriz Silva D’Ambrosio ${ }^{* *}$ \\ Jane Keiser $^{* * *}$ \\ Nirmala Naresh $^{* * * *}$
}

\begin{abstract}
The essence of this paper is to present a self-study that resulted in the awareness of discrepancies that existed between our beliefs and practices as teacher educators and educational researchers. On the one hand, we assessed the impact of our teaching on participants of a professional development program. We analyzed the participants' abilities to explore student voices as input for improving the teaching of mathematics. On the other hand, as we categorized and characterized our participants' reflections using the tools of qualitative inquiry, the end effect was to distort and even silence those voices as an input for improving our own instruction, denying participants both agency and identity. This presented us with a living contradiction since this stance conflicted with our belief that learners deserve both agency and identity.
\end{abstract}

Keywords: Self-study. Mathematics teacher professional development. Teaching practices. Research practices. Living-contradictions.

\footnotetext{
* Doutora em Educação Matemática pela Western Michigan University (WMU), Kalamazoo, MI, USA. Professora e pesquisadora no Departamento de Matemática de Miami University (MU), Oxford OH USA. Endereço para correspondência: Department of Mathematics, Miami University, Oxford OH 45056, USA. Email: dana.cox@miamioh.edu.

** Doutora em Educação Matemática pela Indiana University Bloomington (IUB), Bloomington, IN, USA. Professora e pesquisadora no Departamento de Matemática de Miami University (MU), Oxford OH USA. Endereço para correspondência: Department of Mathematics, Miami University, Oxford OH 45056, USA. Email: dambrobs@miamioh.edu.

${ }^{* * *}$ Doutora em Educação Matemática pela Indiana University Bloomington (IUB), Bloomington, IN, USA. Professora e pesquisadora no Departamento de Matemática de Miami University (MU), Oxford OH USA. Endereço para correspondência: Department of Mathematics, Miami University, Oxford OH 45056, USA. Email: keiserjm@miamioh.edu.

**** Doutora em Educação Matemática pela Illinois State University (ISU), Bloomington-Normal, IL, USA. Professora e pesquisadora no Departamento de Matemática de Miami University (MU), Oxford OH USA. Endereço para correspondência: Department of Mathematics, Miami University, Oxford OH 45056, USA. Email: nareshn2@miamioh.edu.
} 


\section{Resumo}

Neste trabalho apresentamos um "self-study" que resultou numa conscientização de discrepâncias existentes entre nossas crenças e nossas práticas de formadoras de professores e de pesquisadoras. De um lado, avaliávamos o impacto do nosso ensino nas habilidades de participantes do nosso curso de formação continuada para explorarem as vozes de seus alunos e utilizarem essas vozes para melhorar sua prática de ensino de matemática. Por outro lado, conforme fomos categorizando e caracterizando as reflexões dos participantes utilizando as ferramentas da pesquisa qualitativa, acabamos distorcendo e silenciando aquelas vozes que deveriam nos informar para melhorarmos a nossa prática como formadores. Acabamos negando aos participantes tanto autonomia quanto identidade. Isso resultou numa contradição viva, já que esse posicionamento era conflitante com nossa postura de que alunos merecem ambos.

Palavras-chave: "Self-study". Formação continuada. Práticas de formação. Práticas de pesquisa. Contradições vivas.

\section{Overture}

What does it mean to listen to another person as they tell you what they know or explain to you what they have accomplished? What does it entail to suspend all doubts (HARKNESS, 2009) that you may feel about the validity or worth of what they are saying? What does it feel like when you are able to listen, without nagging criticism or imagined response, and embrace the message as if it were your own belief, your own cognitive conflict, or your own accomplishment? What does it mean to truly understand the context in which another person thinks and works? These questions are what we unintentionally unearthed and explored when we set about this project.

The essence of this paper is to present a self-study (GUILFOYLE; HAMILTON; PINNEGAR; PLACIER, 1996) that resulted in an awareness of the discrepancies that existed between our beliefs and practices as teacher educators and educational researchers. On the one hand, we assessed the impact of our teaching on participants' abilities to explore student voices as input for improving the teaching of mathematics. On the other, as we categorized and characterized our participants' reflections using the tools of qualitative inquiry, the end effect was to distort and even silence those voices as input for improving our own instruction, denying participants both agency and identity.

We will tell the story of our shifting research paradigm and journey towards nonevaluative listening in three acts. We begin by introducing the fledgling and flawed assessment of the impact of a professional development experience on participants. We then describe the transformation of that work from an assessment to a self-study of our growth as non-evaluative listeners. We chose this format to reflect the true unfolding nature of the story; 
the insights were gained concurrent with its writing. In this paper, we are, as Whitehead (1989) invites, offering a record of our research practice integrated within our claim to know that practice.

Being a living contradiction carries with it recognition that being personally involved in a given situation may in fact negate the ability to apprehend contradictions in one's own practice - it is very difficult to step back from personal experience and examine it in a detached manner. Self-study calls for this stepping back to happen, it is central to the work of self-study (LOUGHRAN, 2007, p. 20).

We submit to you, our story, which has within it our public acknowledgment of ourselves as living contradictions.

\section{Setting the Stage}

\section{Cast of Characters}

We, the authors, view ourselves as a subset of a larger Community of Practice (CoP) (LAVE; WENGER, 1991). The professional development at the heart of our story was conceived within that larger CoP. Plans were grounded in discussions that included the voices of instructional leaders, administrators, and university faculty members. These discussions were aimed at identifying specific, immediate issues for study that were of interest to everyone within the community. Grounding our professional development thusly, we were able to include multiple perspectives in the planning and identify a course of action that was relevant, motivating, and worthwhile for everyone involved. The resulting plan for professional development was then offered as an option for any and all members of local districts, whether or not they participated in early planning sessions.

The immediate subset of the CoP involved in this self-study is comprised of the authors of this paper, four university faculty members, two of whom were involved in the foundational planning of the PD and two of whom were inducted into the community after the foundational planning of the PD had been completed. In the design of this professional development, we were operating under norms for best practices as defined by the larger mathematics education community. Lesson study (YOSHIDA, 1999; FERNANDEZ; MAKOTO, 2004), using student interviews (SCHIFTER; FOSNOT, 1993) and ThinkerDoers (HART; SCHULTZ; NAJEE-ULLAH, 2004) were all pieces of our instructional plan 
that are defensible with tomes of literature. Our model for professional development was to provide a two-week-long summer workshop, three follow-up lesson studies during the academic year, and a second two-week-long summer workshop.

This smaller CoP focused on assessing the initial two-week summer workshop in order to better recommend alternative courses of future action. One of our main goals for the first summer workshop was to help teachers learn to listen to their students in ways that would allow them to provide more meaningful mathematical instruction. Our premise was that effective teachers who embrace a constructivist approach to learning spend quite a bit of time listening to their students in order to consider what the students understand as they plan their mathematical instruction. One major activity (and the data supporting our study), involved interviews with children. Teachers planned and conducted interviews with children that, whenever possible, would be coming into their classrooms in the fall.

\section{The Setting}

We chose four different school districts (sites) for our post hoc assessment. At each site, 12-15 teachers volunteered to participate in the proposed professional development. To respect the individual district's interests and needs, there was some variation in implementation. Sites differed in terms of the grade band targeted, the mathematical focus of the workshop and the structure of an interview assignment. At two of the sites, teachers interviewed the same student multiple times over the course of two weeks and reflected on portions of that time. At the other two sites, teachers conducted a single one-hour interview with a student and reflected on that experience.

A reflection paper was assigned during the two-week workshop following the interview experience. These papers were the teachers' interpretations of chosen portions of their interviews and a self-report of what they learned about their student's understanding of a mathematical idea as well as their practice. Through their reflective writing, these teachers communicated not only how they engaged with their student, but also how they internalized and interpreted the student's mathematical understanding as well as their pedagogical understanding.

Two over-arching prompts were given with the purpose of having teachers focus on 1) the student's mathematical understanding and 2) implications for their practice, practice being 
inclusive of one-on-one listening behavior as well as whole classroom teaching. In addition to these prompts, we were explicit in wanting teachers to reflect on what the student understood rather than catalog mathematical errors made. Teachers were also asked to transcribe portions of the interviews that were the focus of their reflection. These transcriptions were to be selected because they provided evidence of student understanding of a particular mathematical idea. These written reflections formed the corpus of data that supported our initial assessment of the professional development.

\section{Act 1}

We began the initial assessment with a broad question, "How effective had we been in supporting teachers to become better listeners and to understand the importance of listening to students as a major component of their practice?" Our first assignment was to select a subgroup of reflection papers and read them to get a sense of what our data looked like. This seemingly simple assignment was shrouded in a discussion of purpose and interpretation. Three of us had been responsible for leading the professional development at these sites. The fourth member was unfamiliar with the teachers having not conducted professional development with any of these chosen subgroups. However, she had experiences that familiarized her with the context of the program. Would our discussion benefit or suffer if some of us had familiarity with the teachers? Should we swap papers or read those from teachers with whom we were familiar? Concluding that this added context and familiarity could enrich the conversation, we decided to select the papers of teachers we had worked with when possible. Once we had been assigned to our data, we took personal responsibility for that data that remained throughout the project.

Our goal in reading had been to become familiar with just one subset of the entire data set and become the sole representative of that set of portrayals. We attempted to read with open minds and to be receptive to the teachers' sharing without judgment, so that we were truly in a listening mode, just as we had hoped they would be with their students. Our first meeting together was to discuss this first reading and to familiarize our group with what we had read. In these discussions, we named each teacher and contexts of personal knowledge of these teachers and shared entire summaries of their interview with a student. We will share, through excerpts, two of these stories that became central to our conversation here. 
The first story is Astrid's. At one moment, her incoming eighth-grade student solved $85 \times 28$ by summing $(80 \times 20)$ and $(5 \times 8)$ and she wrote,

At this point, I began to recognize that something wasn't right. I had initially thought David's estimating strategy was a good one, but then I realized when he got 1,640 as his answer that this wasn't the correct answer. I get confused using the partial product method, and so I wasn't exactly sure what David had left out. So I asked if he could show me another strategy for solving this problem.

Later in her reflection, Astrid states,

Between interviews, I really struggled with what really is most important when it comes to teaching math. Do students need to know the traditional algorithm? If they do, how do we get them there? If they don't, how do we help them to be most effective with the strategies they are using?

Our second story is Suki's. Her incoming seventh-grade special needs student solved the problem $50 \times 68$. First, we give an excerpt of her selected transcripts followed by her assessment of her student's thinking.

\footnotetext{
Solve this problem: $50 \times 68=$ ?

Student writes out the problem correctly, but struggles to solve it with any order, algorithm, or sequence. She then makes fifty tally marks.

What strategy are you using?

I am going to make fifty marks, sixty-eight times."

At that time, instructor stops the student and shuts off tape. This problem will be broken down and discussed the second day of interviewing." ...

I also feel that she is a student that needs to work on her overall math facts as a $7^{\text {th }}$ grader. I think she would benefit from a lot of drill and practice with math facts in order to make solving problems less work. She would spend a lot of time using repeated addition for problems that could easily be solved using basic math facts. It was really hard to sit back and let her continue using repeated addition every time it could have been a quick multiplication problem.
}

These stories, and others, were shared as responses to open-ended prompts such as "what did you notice?", "how did the teachers perceive this assignment?" and "how can we characterize the data?" It had been difficult to classify and sort the teachers' reflections. An organizational structure and coding scheme was not immediately clear because of the different perspectives each teacher had taken on the assignment. As exemplified in the stories above, some of the teachers seemed to be very analytical when reflecting on the experience and others simply described the action within the interview. Although each of us attempted to apply our prior experience with qualitative data analysis and identify a coding structure, this was not a simple process. Even as our CoP came to a consensus on what the reflections had in common and how they differed, it was certainly a function of how much of the reflection we considered when coming to that consensus and if it was possible to have multiple 
interpretations of selections and debate the structure of any framework that would position teachers.

We hypothesized that many of these portrayals could be characterized using a matrix. The progression of our thinking after several meetings and discussions is shown in Figure 1. Our initial framework was a 2 × 2 matrix. The categories in columns described the nature of the evidence produced by the teachers in their reflection. In one dimension, we considered the evidence that teachers used when presenting a case of student understanding. We positioned evidence that is primarily imagined or projected events based on teacher's constructions of what teaching and learning could or should look like (rather than on what actually happened) as having a Teacher-Centered Focus. We positioned evidence that represented a focus on student representations, models, tools, strategies, justifications, and/or reasoning as having a Student-Centered Focus.

In the other dimension, we considered the nature of the teachers' reflections on that evidence. When a teacher described events in a literal play-by-play sense, void of interpretation or judgment, we labeled the reflection Descriptive Observation. When a teacher made inferences based on evidence from their descriptions or transcriptions, we labeled the reflection Analytical.

\begin{tabular}{|c|c|c||c|c|c|c|}
\hline \multicolumn{2}{|c|}{ Preliminary Framework } & \multicolumn{4}{c|}{ Extended Framework } \\
\cline { 5 - 7 } & & Inference & & & H68LN \\
\cline { 5 - 7 } $\begin{array}{c}\text { Analytical } \\
\text { Reflection }\end{array}$ & Astrid & Critique & & & H35RR \\
\hline $\begin{array}{c}\text { Descriptive } \\
\text { Observation }\end{array}$ & Suki & & Description & H35JD & H35NT & H36AG \\
\hline & $\begin{array}{c}\text { Teacher- } \\
\text { Centered }\end{array}$ & $\begin{array}{c}\text { Student- } \\
\text { Centered }\end{array}$ & & Teacher & $\begin{array}{c}\text { Student- } \\
\text { Affective }\end{array}$ & $\begin{array}{c}\text { Student - } \\
\text { Mathematical } \\
\text { Understanding }\end{array}$ \\
\hline
\end{tabular}

Figure 1 - The progression of the initial to the extended framework

In this classification, we attempted to position the teachers within the preliminary framework based on their writing in its entirety. The excerpts above were chosen because of their illustrative power, not because they represent all of the data used in this positioning. For example, we positioned Astrid as being student-centered and analytical. Astrid focused on David's thinking in her writing and used it as evidence to explain and draw conclusions about the mathematical understanding of both her student and herself. We positioned Suki as being teacher-centered and descriptive. Suki's writing suggests impatience with her student's 
method of using repeated addition to solve the problem. She also places emphasis on describing and justifying her decisions, both immediate and future, rather than seeking a deeper perspective on the student's understanding of multiplication.

Although Astrid and Suki's papers lent themselves smoothly to this sort of analysis, it was certainly not the case with all of the data, which created enough dissonance for us to step back and reconsider our framework. We agreed that the framework could not be used to characterize all of the teachers. We also agreed that some teachers seemed to fit multiple categories, seeming to analyze some portions of the interview and describe others, or waffle between student- and teacher-centered thinking. In order to continue analysis, we saw the need to abstract the writing in such a way that it severed its ties to any teacher's entire identity and so that individual ideas could serve as exemplars for classification and organization. At this time, we revisited our conversation on bias. In order to reduce perceived bias, we decided to put more anonymous codes on the exemplars to further conceal the teachers' identities.

Figuratively, the teachers' words, sentences, and paragraphs became objects, which we referred to as chunks, to organize, sort, and classify with the accepted caveat that these chunks should not be taken to embody all of a teacher's identity and practice. Literally, some of us took scissors and tape to the papers, chopping them into bite-sized pieces of teacher behavior and reflection. In breaking apart the papers, we agreed that we were removing context from the writing. Before individuals shared the outcomes of their work, additional caveats were made. This is only my interpretation." "Without more context, it is going to be difficult for you to understand this chunk. These new caveats illustrate a general discomfort with the process. Standing alone without background, the chunks changed in meaning. Furthermore, the length of the chunks was highly variable. In some cases, it was impossible to separate the teacher's reflection from the portion of transcribed interview. In other cases, one sentence provided enough context to define and evaluate a complete idea. Although the intention was to pull the data into a layer of abstraction, this was not always as easy as cutting apart a sheet of paper.

As the categorization and organization of chunks continued, the framework expanded to include more diversity in the ways teachers provided evidence and what they chose to do with that evidence. Their ability to really listen to their students and respond in an appropriate way underwhelmed us. We felt that too many of our chunks exemplified judgment on the part of the teacher and we needed more categories on the framework to capture these critical views. 
Also, though some teachers failed to listen to their student's mathematical reasoning, they were attuned to their affect and responded to their emotional well-being. Therefore, it was at this time that we added two-new categories and expanded from a $2 \times 2$ to a $3 \times 3$ matrix (see Figure 1). Along the horizontal axis, the category student-centered was broken into StudentAffect and Student-Understanding. This expanded dimension helped us separate out those teachers who showed genuine concern for a student's mood, behaviors and/or body language from those who focused more on mathematical understandings or behaviors. Along the vertical axis, the Analytical category was broken into two categories, Critique and Inference. Chunks labeled Critique featured teacher evaluations including judgments of mathematical correctness or adequacy of methods or reasoning. Those labeled Inference did not use a preconceived metric by which to judge student reasoning or methods and remained in the worldview of the student. Later, we will refer to this as "giving reason" to the child.

For some cells in our expanded framework (i.e., Teacher Centered/Inference), it was challenging to find benchmarks. Rather than a detriment to the process, the struggle to find benchmarks proved useful to our group. In the cases where no benchmark could be found, we engaged in thought experiments to answer the question, What would a benchmark for this category sound like? What might a teacher write that would illustrate this cell? Although we did not take it so far as to write fictional chunks, we discussed what we would expect them to sound like. In the end, it did not matter that we did not have a benchmark for each cell, but that we could convey the essential meaning of each cell.

With our shifting understanding of that meaning, we acknowledged that we were placing chunks in a fluid sense. In the model, even within a cell, the position of these chunks became relative, their positions less absolute and dependent on both explicit and implicit comparisons to chunks that had already been placed. Some chunks seemed to sit on the fences between cells while others seemed more squarely placed within them. These fence sitters seemed to push us to the conclusion that our model was not complete and did not represent the entire landscape of possibilities. In the example below, there are elements that we interpret as referencing both the student's affect as well as mathematical behavior and thinking. As the writing conflates the two, it is difficult to parse out along the horizontal dimension where to place this chunk.

Fence-Sitter:

Reverting back to this original strategy which was failing him, I felt like Enrique needed more support. Abandoning the protocol, I decided that Enrique did not know 
what 10 looked like well enough to feel successful. Not wanting him to leave the experience with negative feelings or being frustrated, I decided to bring out a tens frame $(\mathrm{HK} 2 \mathrm{GH})$.

Further evidence for this conclusion can be found in the multiple chunks that defied placement within the model. We began to refer to these as wallflowers. We would pick them up now and then and see if they could be placed, but this was challenging and rife with negotiation. In the example below, we were unsure about the meaning behind the use of terms such as "number sense" and were unable to ascertain the true intention of the writer.

Wallflower:

I found this student to be ready for more complex task of combining or going to the next step beyond combining. A more complex way of combining for second grade would be simply to use numbers and symbols to do addition (combining) without the manipulatives. He should be challenged more to use abstract thinking. I heard and saw many skills such as number sense, computation, and thought process being used while he did the problems. He did not use his fingers to point and count. He used his eyes as he followed the groups around. He was very serious about the problems, which gave me insight to his determination to find the answer (HK2KL).

We began to think that the value of our framework was somehow related to the number of chunks we were able to place within it and there was an unspoken sense that once we were able to place them all, the framework would be complete.

At the close of this act, we came to the realization that we had gotten lost in our quest to examine the professional development experience. We had hoped that our framework would have given us scientific tools by which to gauge the impact of our instructional decisions and environmental conditions. We certainly had a data set that included variations such as the duration of student interviews, the mathematical content of our sessions, and even the grade level at which we were working. It was the framework, which we were struggling to create, that we envisioned as the key to identifying direct conclusions about our teaching. We had connected the effectiveness of delivering professional development to our success in moving teachers along a listening continuum that did not seem to be emerging. Simultaneously, we were battling our own disappointment in the data, imagining that the lack of emergent framework might have been caused by our lack of explicitness in the assignment.

We were convinced that we had planned and conducted the professional development based on documented best practices. If we had done the professional development well, teachers would have produced better reflection papers. Our assessment of our professional development had been reduced to evaluating our teachers based on truncated data that we 
were forced to interpret. We do not believe that student performance should be a sole determiner of teacher quality, however, we superimposed that same illogical reasoning in thinking about our own professional development practice.

As we began to embrace the limitations of our model, we paused in our work together to take the show on the road. Presenting the work to the larger field of Mathematics Education, we sought answers to questions. What would others find within our model? How would they characterize the chunks that we were struggling to place? Would others affirm the decisions that we had made? It should be noted that another question is missing from this list, one that would not occur to us until much later. Why have we not yet attended to our own evaluative listening?

\title{
Act 2
}

This act is about becoming aware of the contradictory nature of our work and our fallibility as teachers. Our mood was confident and we felt that we had something significant to present to others. In a proposal for a poster session at a research conference, we wrote:

\begin{abstract}
It is clear from our preliminary analysis of the written reflections that it is difficult for teachers to engage in non-evaluative listening and that, upon reflection, teachers became aware of the challenges. One particular challenge was overcoming the urge to provide corrective instruction during the interview. As one teacher wrote, 'Throughout this interview it was evident to me that the decisions I made as an interviewer and observer were critical to the information that I gained...It is pertinent that I think more critically about the unplanned questions I asked during the interview. The decisions made and wording chosen can change the course of the interview or completely skew the information gathered from the student.' Additional findings will be featured on the poster.
\end{abstract}

In planning a poster to bring to the meeting, we faced a unique challenge. Traditionally, a poster presentation would be a snapshot of a work-in-progress. Following convention, we would have featured our framework and described how it was useful for our assessment of our teachers' learning to listen. As we designed this poster, we were convinced that the framework was not the important contribution of our work. Instead, we felt that the process underwent in order to create and vet the framework was compelling. We really wanted people to see how the framework had served as a tool for identifying, interpreting, and classifying chunks.

We considered many representations of the work that would help bring this process to the forefront. In fact, as we considered different representations, our ongoing discussion of 
classifying chunks took another turn. Are the categories truly positions along a continuous line as we hypothesized? If they represent continua, are the labels well ordered? Specifically, is it better to describe student thinking without judgment or to offer a mathematical critique? Could we envision the purpose of our professional development as a diagonal shift from the lower left-hand box to the upper right?

In the end, we decided to bring our discussion directly into the public eye with a nontraditional poster presentation. Instead of presenting a formal snapshot of our thinking in this matter, we created a poster that had the potential of immediately involving audience members in the discussion by asking them to engage in the interpretation and classification of chunks on the spot. Our poster was a large-scale version of the extended framework (see figure 1) with embedded description and definitions. The only other information on the poster was contact information, a brief description of our purpose, and our research questions. We designed it to quickly initiate someone to the conversation before asking them to participate.

Our presentation style was non-traditional because it was based on the expectation of a new discourse style. We would not be attempting to convey our project in its entirety to someone else, but instead, we would be initiating others into our community of practice, much like this paper. The poster was well attended by people who spent a significant amount of time thinking with us about our chunks. We had printed a few chunks in boxes on the poster to serve as benchmarks for categories, just as we have here in this paper. We also printed four different chunks on paper slips and asked audience members to read them and then place them within our framework. Within the four selected chunks were our examples of both a fencesitter and a wallflower.

Through discussion, we received affirmation that what we were doing was interesting and important. In terms of the non-traditional presentation, we received three specific affirmations. First, our choices of printed chunks were appropriate and helpful in starting conversations about practice. Although the audience did not know the authors of these chunks, they recognized the ideas within them as representing something familiar. Many of the audience members were currently engaged in their own professional development work and used this context to relate further to the chunks. Second, all audience members affirmed that placing chunks was difficult work, but compelling and educational. The conversations that ensued were not just about the wording on the slip of paper, but also about what these abstract ideas meant in terms of the goals and purpose of professional development. Third, these 
conversations affirmed the value of our thought experiments. Those audience members who stayed long enough to have placed multiple chunks within the framework were also compelled to think about why some of the boxes within our framework remained blank. They, too, began to invent abstract reflections that might represent these unknown intersections.

In terms of our framework, we received affirmation that it fit our data. All agreed that the axes behaved more like continua than discrete categories. Others saw the diagonal shift that we described and commented that this represented the goal of our professional development activity. We also received affirmation that the limitations we perceived in our framework were present. When placing chunks, audience members saw the relational position of them within categories and agreed that our fence-sitters really did teeter on the edge of multiple types of reflection practice. They, too, struggled to place the wallflower and agreed that there seemed to be some characterizations of reflection that were missing from this framework and struggled to imagine what they might be. What would a category that included this wallflower be called?

One outcome that we had not expected was a view raised during the presentation. Identifying the diagonal shift as being important and relevant, participants began to imagine ways to use this framework as an assessment tool for local projects. Using a pre/post-test model, participants wanted to track teachers' progress over time by placing vectors within a two-coordinate system that represented these shifts for individuals. This interpretation of our work, both in the moment and in its future retelling within our group, reflected to us like a mirror the true nature of our work. Juxtaposed with teaching teachers to listen in a nonevaluative manner was our own story as teachers, listening in judgment of our students.

What we did not receive was the challenge we most needed to hear. No one asked us, how dare you talk about teachers this way? In hindsight, there was a glaring issue in the study as we presented it--its very theoretical perspective. Having someone point out the contradictions between our empirical and evaluative stance and our beliefs about teaching would have been helpful. As such, the impetus for exploring these contradictions would come from within our group rather from the field itself. 


\title{
Intermission
}

At this junction, readers may be critically evaluating the study we have described thus far. Some readers may be craving more detail regarding the qualitative study, the techniques we used for triangulation, the methods we used to conduct analysis, and the potential for our work to be trustworthy and valid. The reader may imagine that the lack of detail suggests a poorly designed study, or find a mismatch between the research purpose and the methodology chosen. In the format of a traditional qualitative research report with Act One at the center, these assumptions could all be valid. We encourage readers to suspend doubt, and remind them that the journey described here transcends the questions of rigor and methodology and brings into focus the theoretical perspective itself; the flaws in Act One pale in comparison to our realizations in Act Three.

Up to this point, we were positioned in our work as researchers studying our implementation of professional development while embracing a qualitative research design and methodology. Within this perspective, the boundaries between the researchers and subjects are clearly delineated. Whereas in Acts 1 and 2 we positioned ourselves objective observers, in Act 3 we transitioned slowly to the point where we became the subjects of our scrutiny. At this point, the contradictions that were emerging were our own and we embraced the methodology of self-study. It was our work as professional development providers, teachers, and researchers, in essence "ourselves" that we found interesting and this was the story we are compelled to tell. Our work was shifting from a mere analysis of concrete data to an introspection and deep reflection of the complexities of our practices.

\section{Act 3}

\begin{abstract}
At times this research has caused me great anguish as I have begun to pull apart some of this accepted knowledge about societal relationships. The level of selfreflexiveness required in postmodern research means that to be useful some of the things that we feel make up who we are, such as our role in society, need to be critiqued and will be found wanting (MEANEY, 2004, p. 196).
\end{abstract}

To become more aware of our evaluative nature and the contradiction we were living, it would take three key forces: A personal reflection from a colleague, a study group on postmodern thinking, and the act of trying to write our story. In this act, we describe how our colleague's sharing of a personal story served as a seed that challenged our evaluative stance 
and triggered deep personal reflection. The story was powerful in that it was a concrete example shared in the broader context of a study group on postmodern thinking. However, that context alone had not been enough to provoke the personal shift; our attempts to write down the story of our project provided the concrete link between theory and our practice.

\section{A Personal Reflection}

The reflection is in first-person narrative. A group of mathematics educators attending an international conference was invited to observe and experience local mathematics classrooms. The purpose was to understand the local context and culture of mathematics teaching, a context and culture unfamiliar to attendees. I traveled with a small group of mathematics educators to observe a day at a government-funded elementary school. Children dressed in their best uniforms, wearing fresh flowers in their braided hair, and performing traditional songs and dances gave us a warm welcome. The lesson I observed was in a classroom studying 3-D geometry. There were interesting artifacts on display including local containers used to measure milk along with tins and boxes presumably used to talk about the volume of prisms. The teacher appeared proud of the lesson and artifacts used, and eager to give students a stage on which to demonstrate what they knew. We witnessed many recitations and demonstrations by eager students who waived their hands wildly to signal to the teacher that they were ready to shine. Both the teacher and the children had worked hard to impress the visitors. At the end of the lesson, we had the opportunity to ask the teacher questions about the lesson and about the school. Few questions were asked, and those few were along the lines of "How long has this lesson been going on?"

The next morning, the group of mathematics educators reconvened outside of the context of the school. Immediately, the conversation turned to a discussion of what we had seen. We had not been there in the capacity of evaluation, yet that role we automatically assumed.

The criticisms flew around the table indicting not only the actions and decisions made by the teacher, but also the skill of the students.

The lesson was taught by rote. The students were memorizing and not reasoning. There was too much focus on multiplication facts and too little on measurement concepts or problem solving. If the lesson had been rehearsed (it must have been), then who knows if the students even understood what they had been asked to recite and demonstrate? (anonymous participant) 
I, like others in the group, was comfortable dissecting the lesson and took license in judging what we had seen without any further context or background.

The Group Reacts to the Reflection. Once this story was shared, our group began to reflect on the act of observing teaching and learning. This particular story evoked concerns about the evaluative stance that is so natural to the work of studying teaching and learning. As we discussed the story together as a group, we discovered empathy for the teacher and the students and regretted the missed opportunity to understand the complexity of a specific act of teaching. The opportunity to uncover that complexity and truly understand the dynamics of the lesson had been given. The teacher had invited questions and discussion, yet no one had thought to ask about the specific needs of the teacher, students, and community and why this particular lesson could help fulfill those needs. The group had denied the teacher and students reason. Who gives mathematics educators the right to judge teachers and their enactments? Are we such experts that we can, on first sight and without economic, political or cultural context, determine the value of an instructional episode? How quickly we strip teachers of agency (VALERO, 2004) and identity (BROWN; JONES; BIBBY, 2004).

\section{A Postmodern Study Group}

Concurrently with our study, we were all involved in a book study of Mathematics Education Within the Postmodern (WALSHAW, 2004). Each week we met to discuss a different chapter, each of us taking turns facilitating that discussion. Some chapters we discussed for multiple weeks, arriving at insights we valued and took personally. These discussions were humbling for many of us as we began to see similarities in our thinking about our "students" and the structures in our educational system that oppress students and teachers. The constructs of power, agency, privilege, identity and oppression were particularly central to our discussions and seemed relevant to our work with students and teachers.

This was all in a general abstract sense. It was not until we began writing up the results of our work and shared the story above that our thinking on these matters became concrete and available for application. It was as if the pieces of a jigsaw were flying about in the ether, but had finally begun to arrange themselves in a way to create a picture of our practice. It was very much like the experience shared by Valero (2004), "my postmodern 
attitude did not result from a conscious paradigm selection; rather, it was constructed as I met school leaders, teachers and students in different schools in the world whose lives shook me in significant ways" (p. 36).

The reflection above was an obvious example in which we could identify the power structures that existed and apply these new principles at a distance. Much more challenging was the application of these principles to our practice. As we continued to revise and reconsider our work in framing the work of teacher listening, we faced this challenge head on. Participation in this study group caused us to question the act of characterizing individuals within any framework, and particularly the one we had developed. We expected our teachers to gain respect for the whole student and not parcel their perceptions into evaluative boxes like "mathematically correct." And yet, we were doing this for them. We were being evaluative listeners and positioning them according to our own lens, denying them voice and reason in their own practice. At this point, our conversation and the purpose of writing shifted in substantive ways. As one member stated, “As I analyzed reflections, I felt more empathy for the teachers and aware of the difficulty of what we were asking them to do and the vulnerability it required. "

\section{Documenting Our Journey}

Documenting our journey was difficult primarily in finding a recognizable and accepted structure for the story. Second, it was difficult because the story kept unfolding with each new draft; insights about our practice both in terms of our teaching and our research continued to deepen and emerge. We began thinking of our work through the lens of action research (LEWIN, 1946). We had student work to analyze and we knew we had much to learn from that analysis. In early drafts, we sought to describe how we used the artifacts produced by our teacher participants to inform our practice. We were troubled by the positivist language we found ourselves using such as classifying our teachers' reflections as data. Reflection papers were such a small window into a teacher's practice as it is, we struggled even more with the thought of using a truncated version of that, stripped of identity and context, to position teachers against our evolving framework, which really represented an external ideal-divorced by nature from the actual context of teaching. 
It was only after we allowed ourselves to drop the false boundaries called for by a typical report of research that we were able to express the most interesting insights of our work. It was the story of our emerging perspective on our teaching and research that was interesting to us, a story that was not necessarily tied to a specific data set, but in our developing reflection on our practice. It was a story that unfolded simultaneously with its telling. Each draft opened up new ideas and offered new insights. What we were searching for was a metacognitive perspective that would allow us to rise above specific activities such as the development of a framework and instead focus on what we learned about ourselves having engaged.

What began as a paper about what we could learn from our teacher's writing samples became a story about the development of a faulty framework - one that revealed to us the limitations of our thinking and the contradiction between assuming an evaluative stance (that gave teachers neither agency nor identity) and preaching that mathematics students deserve both. The hidden rubric in our brains about what good teaching is supposed to look like became apparent in our attempts to match teachers against that elusive ideal. However, it was not until we tried to document that rubric that we realized the futility of imagining one at all let alone one that would fit each individual with whom we had worked. In fact, the lessons that we were finally able to learn from our book study were only possible in the broader context of our genuine efforts to examine our practice. Nor were the lessons to be learned from our practice apparent until we were able to apply the theory learned in that study group; application that was not possible until the concrete example was shared by a colleague.

According to Whitehead (2009), the practitioner addressing the question "How do I improve what I am doing?" will engage in a reflection that will illuminate their living contradiction. As he explains: "I am thinking here of 'I' existing as a contradiction in the sense of holding together a commitment to live certain values with the recognition of the denial of these values in practice" (p. 87).

We chose a qualitative research design to best address our research purpose. The qualitative research design that we adhered to denied us our values - to respect and honor teachers' voices - the very values that we wanted our teachers to accept as a critical component of good teaching. In our quest to be scientific and methodical in our research process, we identified a data set i.e., teachers' written reflections, that we analyzed and interpreted using the tools of qualitative inquiry. As warranted by the norms of academic 
research involving human subjects, we were concerned about preserving anonymity and remaining unbiased in our interpretations of data. This led us to devise coding mechanisms that masked teachers' identities. Also, in an effort to make more of their statements fit our framework, we cut up entire reflection papers into smaller chunks. All of this manipulation of data fragmented the teachers' work and thus created an abyss between the teachers' reflections and the context in which they had been operating. In concealing the teachers' identities we were no longer able to honor their voices and engage in non-evaluative listening. We had interpreted teachers' writing without considering the social, political and cultural realities of teaching. In retrospect, adopting a self-study paradigm instigated us to be more attentive to the role of context in shaping our practices (PINNEGAR; HAMILTON, 2009).

As constructivist teachers, when teaching mathematics, we have learned, for the most part, how to give reason (DUCKWORTH, 1987) to our students as we listen to their mathematical voices. We have learned how to embrace the mathematics of students in shaping our knowledge of mathematics. We are effective in suspending doubt (HARKNESS, 2009) as our students describe their mathematical thinking. For the most part, we honor and respect the mathematical voices of our students. For this reason, we create a learning environment where we are co-constructors of mathematics with our students. Our analysis of our work with teachers led us to question why we are able to give reason to learners when dealing with mathematics, but so unable to give reason to the learner when dealing with teaching. We seem to have a pre-conceived vision of what constitutes good teaching and are unable to hear the voices of teachers with alternative perspectives - perspectives that grew out of living within a social, political and cultural reality to which we are strangers.

\section{Epilogue}

This paper is less about the communication of polished solutions or findings and more about the uncomfortable and messy work of examining practice and documenting shifts in our identities as teachers and researchers. Through this self-study, we became aware of tensions between our practice and ideals, fitting the aim of self-study, i.e. "to provoke, challenge, and illuminate rather than confirm and settle," (BULLOUGH; PINNEGAR, 2001, p. 20).

On the research front, this work has pushed us to question the implicit roles that are assumed within existing research paradigms and methods and to imagine what forms research 
might take if we are to award teachers with the identity and agency we feel they deserve. Selfstudy "offers a fresh perspective on established truth and has an emotional impact," (KORTHAGEN; LUNENBERG, 2007, p. 444). We cannot deny the impact our work has had on ourselves, both emotionally and professionally. Many times, we have stepped away from the work seeking perspective and balance as our worldview churned around us. We have found some stability in thinking of our future research in terms of a partnership with teachers and students examining the realities and complexities of our profession.

The living contradiction in our teaching has caused us to question many of our typical practices as mathematics educators, especially in the role of professional development providers or math consultants to districts and schools. We want to do work that respects, maintains the dignity of our teachers, and gives them autonomy in constructing a picture of ideal practice. We have begun to acknowledge the value of co-constructing meaning alongside teachers, but need to explore models for how we can accomplish this. In the past, we have often engaged in practices such as:

a) accepting the challenge of helping a teacher "improve" her practice based on just a few observations;

b) watching short video-clips of teachers at professional conferences and drawing inferences about their practice as a whole;

c) making judgments about teacher practices from knowing the textbooks adopted by their districts;

d) consulting with schools or districts and accepting the administrator's assessment of their staff; and

e) designing professional development experiences based upon our expert analysis of student performance data.

In hindsight, we realize that in each of these instances we have positioned ourselves as experts and denied our teachers agency and identity. We now ask, what does it mean to engage in professional development with teachers without assuming an evaluative stance? How should we approach our work together with teachers without a preconceived notion of what is there to be learned or taught? We want to move from being imparters of teaching knowledge to being co-conspirators in the act of examining and defining good practice. Perhaps the best next step we can take is to continue to talk about our own learning and to further document a living theory (WHITEHEAD, 2009). 


\section{References}

GUILFOYLE, K.; HAMILTON, M. L.; PINNEGAR, S.; PLACIER, M. Negotiating balance between reforming teacher education and forming self as teacher educator. Teacher Education Quarterly, San Francisco, v. 23, n. 3, p. 153-168, jun./aug. 1996.

BROWN, T.; JONES, L.; BIBBY, T. Identifying with mathematics in initial teacher training. In: WALSHAW, M. (Ed.). Mathematics education within the postmodern. Greenwich, CT:Information Age, 2004. p. 161-179.

BULLOUGH, R. V.; PINNEGAR, S. Guidelines for quality in autobiographical forms of self-study research. Educational researcher, Washington D.C., v. 30, n. 3, p. 13-21, abr. 2001.

DUCKWORTH, E. "The Having of Wonderful Ideas" \& other essays on teaching \& learning. New York: Teachers College Press, 1987.

FERNANDEZ, C.; YOSHIDA, M. Lesson study: A Japanese approach to improving mathematics teaching and learning. Mahwah, NJ: Lawrence Erlbaum Associates, 2004.

HARKNESS, S. S. Social constructivism and the Believing Game: a mathematics teacher's practice and its implications. Educational Studies in Mathematics, v. 70, n. 3, p. 243-258, 2009.

HART, L. C.; NAJEE-ULLAH, D.; SCHULTZ, K. The reflective teaching model: A professional development model for in-service mathematics teachers. In: RUBENSTEIN, R.N.; BRIGHT, G.W. (Ed.). Perspectives on the teaching of mathematics: Sixty-sixth yearbook. Reston, VA: NCTM, 2004. p. 207-218.

KORTHAGEN, F; LUNENBERG, M. Links between Self-Study and Teacher Education Reform. In: LOUGHRAN, J. J.; HAMILTON. M. L.; LABOSKEY, V. K.; RUSSEL, T. (Ed.). International handbook of self-study of teaching and teacher education practices. Dordrecht, Netherlands: Springer, 2004. p. 421-449.

LAVE, J.; WENGER, E. Situated learning: Legitimate peripheral participation. Cambridge: Cambridge University press, 1991.

LEWIN, K. Action research and minority problems. Journal of social issues, Malden, v. 2, n. 4, p. 34-46, Nov. 1946.

LOUGHRAN, J. J. A history and context of self-study of teaching and teacher education practices. In: LOUGHRAN, J. J.; HAMILTON. M. L.; LABOSKEY, V. K.; RUSSEL, T. (Ed.). International handbook of self-study of teaching and teacher education practices. Dordrecht, Netherlands: Springer, 2004. p. 7-39.

MEANEY, T. So what's power got to do with it?. In: WALSHAW, M. (Ed.). Mathematics education within the postmodern. Greenwich, CT: Information Age, 2004. p. 181-200.

PINNEGAR, S.; HAMILTON, M.L. Self-study of practice as a genre of qualitative research: Theory, methodology, and practice. New York: Springer, 2009. 
SCHIFTER, D.; FOSNOT, C. T. Reconstructing mathematics education: Stories of teachers meeting the challenge of reform. New York: Teachers College Press, 1993.

VALERO, P. Postmodernism as an attitude of critique to dominant mathematics education research. In: WALSHAW, M. (Ed.). Mathematics education within the postmodern. Greenwich, CT: Information Age, 2004. p. 35-54.

WALSHAW, M. (Ed.). Mathematics education within the postmodern. Greenwich, CT: Information Age, 2004.

WHITEHEAD, J. Creating a living educational theory from questions of the kind, "How do I improve my practice?”. Cambridge Journal of Education, Cambridge, v. 19, n. 1, p. 41-52, 1989.

WHITEHEAD, J. Self-study, living educational theories, and the generation of educational knowledge. Studying Teacher Education, London, v.5, n.2, p.107-111, 2009.

YOSHIDA, M. Lesson study: An ethnographic investigation of school-based teacher development in Japan. Chicago, Unpublished doctoral dissertation, Universityof Chicago, 1999.

Submetido em Agosto de 2013. Aprovado em Janeiro de 2014. 